\title{
Qualification Problem in Administrative Law
}

\author{
Jakub Handrlica**
}

\begin{abstract}
How do we qualify the foreign administrative decisions that enable legal effects in municipal law? This procedural question, labelled as 'the qualification problem' in legal scholarship, triggers the attention of both theorists and legal practitioners. The qualification problem arises in those cases where municipal law requires any form of administrative action of the domestic administrative authority towards a foreign administrative decision. Here, the domestic administrative authority faces the problem of how to qualify these administrative decisions. In principle, three various approaches may be considered - qualification based on lex causae, lex fori, or autonomous understandings would theoretically be possible. This article argues in favour of the exclusive use of lex fori in such situations.
\end{abstract}

\section{Keywords}

Qualification Problem; International Administrative Law; Procedural Law; Lex Fori; Lex Causae; Autonomous Qualification.

\begin{abstract}
Abstrakt
Jakým zpisobem kvalifikovat právni povahu cižich správnich aktu, které podle prédpisu našeho vnitrostátního práva vyvolávaji právni úcinkey v rovinè našeho práva? Tato otázka, označovaná v odborné literature jako „kvalifikeačni problém“, dloubodobě budi zájem nejenom právni teorie, ale také právní praxe. Pri kvalifikaci cizich správnich aktù má tuzemský správni orgán v zásadè trü možnosti: kvalifikace na základě legis fori, legis causae, nebo kvalifikaci na základè autonomníbo pojetí. Tento článek prédkládá argumenty pro kvalifikeaci cizích spráunich aktů na zákeladě legis fori.
\end{abstract}

\section{Klíčová slova}

Kvalifikačni problém; meainárodníprávo správní; procesni právo; lex fori; lex causae; autonomni kvalifikace.

\footnotetext{
* This contribution was written under the umbrella of my research project "International Administrative Law: Legal Discipline Rediscovered", supported by the Czech Science Foundation (reg. no. 20-01320S). Sincere thanks go to Professor Giacinto della Cananea (Bocconi University, Milan) and to Professor Jean-Bernard Auby (Science Po, Paris) for their comments and recommendations to the draft of this article.

** Doc. JUDr. Jakub Handrlica, LL.M., Ph.D., Department of Administrative Law and Administrative Science, Faculty of Law, Charles University, Prague, Czech Republic / Katedra správního práva a správní vědy, Právnická fakulta, Univerzita Karlova, Praha / E-mail: jakub.handrlica@prf.cuni.cz / ORCID: 0000-0003-2274-0221
} 


\section{Introduction}

In order to introduce the qualification problem to a reader of this article, three examples from the existing statutory laws will be given:

a) Regulation (EC) $810 / 2009^{1}$ provides that uniform visas that are valid for the entire territory of the Member States ${ }^{2}$ are to be issued to third country nationals by those Member States that represent the sole destination of the visit. ${ }^{3}$ However, if the visit includes more than one destination, the Member State whose territory constitutes the main destination of the visit in terms of length and purpose of stay is competent to examine and decide upon an application for a uniform visa. ${ }^{4}$ Such uniform visa will also be valid for territory of other Member States.

In the case where no main destination can be determined, the Member State whose external border the applicant intends to cross is competent to issue the uniform visa. ${ }^{5}$ In this case, the visa will also have validity in the territory of the other Member States. Further, the Regulation provides for rules on annulment and revocation of issued visas. ${ }^{6}$ Here, it is provided that a visa shall, in principle, be annulled by the competent authorities of the Member State that issued it. However, a visa may also be annulled by the competent authorities of another Member State, in which case the authorities of the Member State that issued the visa shall be informed of such annulment. $^{7}$

b) Act No. 361/2000 Coll., on road traffic, provides for the validity of certain foreign driving licences in our territory. Pursuant to this statutory law, within the territory of the Czech Republic, the right to drive a motor car can also be certified by a driving licence, issued by another Member State ${ }^{8}$, by a Contracting Party to the Vienna Convention on Road Traffic of $1968^{9}$, or by the Geneva Convention on Road Traffic of $1949 .{ }^{10}$ Further, the statutory law provides ${ }^{11}$ that the domestic administrative authority is in certain situations required to replace a foreign driving licence for the domestic one. In this regard, it is provided, that "in case of doubts about the validity of the foreign driving license", the domestic administrative authority must

1 Regulation (EC) No 810/2009 of 13 July 2009 establishing a Community Code on Visas (Visa Code), OJ L 243 of 15. 9. 2009.

2 Ibid, Art. 2.3.

3 Ibid, Art. 5.1.a.

4 Ibid, Art. 5.1.b.

5 Ibid, Art. 5.1.c.

6 Ibid, Art. 34.1.

7 Ibid.

8 Act No. 361/2000 Coll., on road traffic, \ 104 (2) b.

9 Ibid, $\int 104$ (2) c.

10 Ibid.

11 Ibid, $\int 116(3)$. 
approach the diplomatic representation of the State that issued the foreign licence. ${ }^{12}$ Thus, in evaluation of the validity of the foreign driving licence, the domestic administrative authority must qualify such a licence.

c) Act No. 240/2013 Coll., on investment companies and investment funds, provides that licences issued by competent authorities of other Member States are also valid in inland. ${ }^{13}$ Further, the statutory law provides for a special provision, entitled "Violation of the foreign law". ${ }^{14}$ The domestic administrative authority (National Bank) is here required to take necessary measures vis-á-vis a holder of a foreign licence, who is providing investment services in our territory. Such measures are to be taken in cases where the competent authority of the home State of such licence holder will notify the National Bank that this licence holder is violating his notification obligations, as provided by the applicable law of the home State.

Here, the National Bank has, inter alia, competence to "to restrict the scope of the licence, or to stipulate requirements for pursuing of certain activities". ${ }^{15}$ If applying this competence, the domestic administrative authority will be required to open a review proceeding with concern to the foreign licence in order to "restrict its scope". In such a review proceeding, the domestic administrative authority will face the problem of qualification of the respective foreign licence.

Despite dealing with different areas of public administration, all three above mentioned examples share common problems:

Firstly, in all above referred cases, the statutory laws directly (ex lege) provide for validity of foreign administrative decisions in inland. Secondly, the applicable statutory laws simultaneously provide that the domestic administrative authority is competent to execute certain procedural measures vis-á-vis the foreign administrative decisions. Regarding the framework established under the Regulation (EC) 810/2009, the domestic administrative authority possesses the competence to annul a visa issued by a consulate of another Member State. Under the framework of the Act No. 361/2000 Coll, the domestic administrative authority must review the validity of a foreign driving licence. Lastly, the Act No. 240/2013 Coll. provides for the competence of the domestic administrative authority to restrict the scope of a foreign licence for providing investment services.

Consequently, if executing these procedural measures, the domestic administrative authorities must qualify the legal nature of the corresponding foreign administrative decision. Only if this qualification is properly carried out, can the procedural measures conducted by the domestic administrative authorities be deemed as legal. Thus, in all mentioned cases, the qualification problem arises as a problem of procedural

12 Ibid.

13 Act No. 240/2013 Coll., on investment companies and investment funds, \328-336.

14 Ibid, $\int 571$.

15 Ibid, $\int 539$ h. 
law - the domestic administrative authority may potentially use either municipal law (lex fori) or make use of the legal framework of the State, which issued the respective administrative decision (lex causae). Alternatively, the competent administrative authority may also theoretically use an autonomous qualification of such foreign administrative decision, considering it as an act sui generis.

This paper reflects the increasing tendency to provide for validity of foreign administrative decisions that are frequently the result of implementation of EU law and thus increase the probability of dealing with the qualification problem. As our statutory laws do not address the qualification problem explicitly in their provisions, this paper aims to provide an analysis of this issue from the viewpoint of our administrative law. ${ }^{16}$ However, being written in English, it also aspires to represent a contribution to the international academic discussion on the topic. ${ }^{17}$

The aim of the article will be addressed in the following way: Firstly, clarification of the terms "administrative decision" ("foreign administrative decision" respectively), "recognition", "inland" and "the State of origin" will be provided, as such clarification is necessary for an overall understanding of the paper. Secondly, a review of existing foreign literature dealing with the subject of this study will be provided. In the third section, three approaches to the qualification problem will be analysed. Here, advantages and disadvantages of each approach will be addressed. This part will present arguments for why lex fori represents the only viable option, as well as how domestic administrative authorities must address any foreign administrative decisions.

Lastly, one final remark to the scope of this article must be included. This article will deal exclusively with those cases in which domestic administrative authorities deal with a foreign element in the matters of public law. Consequently, situations where domestic administrative authorities must deal with a foreign element in the relations of private law, are not subject of this article and are left as a subject of attention for the scholarship of international private law.

16 The issue has been only rarely addressed in our scholarship of administrative law. Here, I can refer to the published version of my habilitation thesis, which briefly dealt with the issue few years ago and to my article summarising the key ideas of these thesis in English, see HANDRLICA, J. Transteritoriáln správni ak.ty. Studie z mezinárodníbo správního práva [Transterritorial administrative acts. A study in international administrative law]. Praha: Studie Národohospodářského ústavu Josefa Hlávky, 2017 (the qualification problem was addressed here at pp. 64-68); and HANDRLICA, J. A treatise for international administrative law. Part II. On overgrown paths. Lawyer Quarterly, 2021, Vol. 11, no. 1, pp. 1-20.

17 See e.g. OEHLER, C. Die Kollisionsordnung des Allgemeinen Verwaltungsrechts. Tübingen: Mohr Siebeck, 2005, pp. 313-323; MENZEL, J. Internationales Öffentliches Recht. Verfassungs- und Verwaltungs-grenzrecht in Zeiten offener Staatlichkeit. Tübingen: Mohr Siebeck, 2011, pp. 336-337; RODRIGUÉZ ARANA MUÑOZ, J. (ed.). Recognition of Foreign Administrative Acts. New York: Springer, 2016 (here, the national reports on recognition of foreign administrative acts, presented at the XIX ${ }^{\text {th }}$ Congress of the International Academy of Comparative Law, were published); most recently HEMLER, A. Die Methodik der "Eingriffsnorm" im modernen Kollisionsrecht. Tübingen: Mohr Siebeck, 2019, pp. 62-64. 


\section{Terminological clarification}

Having introduced the subject of this study, the following remarks serve to clarify the terminology used in this article:

- Firstly, this article uses an umbrella term for a myriad of unilateral forms of administrative measures that appear in various jurisdictions. The fact is that there are no common terms labelling these unilateral measures of public administration, which created issues in a formalised administrative proceeding. Thus, a qualification of a measure in the State of its origin (i.e. a qualification by using the lex causae) and the qualification of the same measure, using lex fori in inland, can differ considerably. ${ }^{18}$ In this regard, the qualification problem was labelled a result of "divergencies in legal and administrative traditions of the respective jurisdictions". ${ }^{19}$

Within the scholarship, the term foreign administrative acts is frequently used in this context. ${ }^{20}$ Due to the fact that the qualification problem represents a problem of procedural law, this article will use the term foreign administrative decision as an umbrella term. This choice is made due to our domestic tradition, in which the term "decision" refers to a procedural feature. Thus, these terms will be used to address all types of unilateral administrative measures issued by the competent administrative authority of the State in an administrative proceeding. Thus, referring to the "administrative decision", this article will also understand unilateral measures, such as university diplomas, driver's licences, visas etc., which are not necessary classified as "administrative decisions" in each of the jurisdictions. Despite its shortcomings, such a terminological approach is also currently generally accepted by other scholars. ${ }^{21}$

- Secondly, the term "recognition ex lege" will be used to refer to those situations where provisions of municipal law provide directly for legal effects of foreign

18 See e.g. REINACHER, K. Die Vergemeinschaftung von Verwaltungsverfahren am Beispiel der Freisetzungsrichtlinie. Berlin: Tenea Verlag, 2005, pp. 61-62 (here, the author points out, that qualification problems can potentially arise by mutual recognition of foreign public contracts, or individual-abstract acts); GERONTAS, A. Deterritorialization in Administrative Law: Exploring Transnational Administrative Decisions. Columbia Journal of European Law, 2013, Vol. 19, no. 3, pp. 432-433 (here, the author provides for comparison of the terms "Verwaltungsakt" in the German jurisdiction and "acte administrative" in the French jurisdiction); SCHWARZ, M. Grundlinien der Anerkennung im Raum der Freibeit, der Sicherbeit und des Rechts. Tübingen: Mohr Siebeck, 2016, pp. 70-71 (here, the author argues, that the institute of Verwaltungsaket has actually no appropriate corresponding pendant in any European jurisdiction).

19 SCHWARZ, H. Die Annerkennung ausländischer Staatsakte. Berlin: Verlag Grünewald, 1935, p. 30.

20 See e.g. various national reports, published in RODRIGUÉZ ARANA MUÑOZ, J. (ed.). Recognition of Foreign Administrative Acts; Other authors opted for other umbrella terms, such as "public acts", or "quasi-public acts". See e.g. PAMBOUKIS, C. L'acte quasi public en droit international privé. Revue critique de droit international privé, 1993, Vol. 42, no. 5, pp. 565-590.

21 See e.g. WENANDER, H. Recognition of Foreign Administrative Decisions. Balancing International Co-operation, National Self-Determination, and Individual Rights. Zeitschrift für ausländisches öffentliches Recht und Völkerrecht, 2011, Vol. 71, pp. 755-785. 
administrative decisions in inland. Under this scheme ${ }^{22}$, a foreign administrative decision gains effects in inland by the virtue of a provision provided by a statutory law. ${ }^{23}$ Consequently, this scheme does not require that the domestic administrative authorities formally decide upon the recognition. On the other hand, the term "recognition ex actu" 24 will address those cases where domestic administrative authorities actively (by their own decisions) recognise foreign administrative decisions. ${ }^{25}$ Under this scheme, effects arise directly by virtue of a domestic administrative decision (a decision of recognition). The umbrella term "recognition" will address both cases of recognition ex lege and recognition ex actu, i.e. all cases in which a foreign administrative decision is treated as valid in an individual case. ${ }^{26}$

- Lastly, the article is written from the perspective of the Czech Republic, which in this context is also being referred to as "inland". The legal framework of the Czech Republic will be referred as "municipal law". The State, where a foreign administrative decision was issued, will be referred to as "the State of origin". The term "applicable law" will be used as an umbrella term for domestic legal frameworks in various jurisdictions.

22 The terminology varies in recent legal scholarship, see e.g. NGUYEN, M. Droit administratif international. Zeitschrift für schweizerisches Recht, 2007, Vol. 125, no. 3, p. 122 (reconnaissance de par la loi); ARMSTRONG, K. Mutual recognition. In: BARNARD, C. and J. SCOTT (eds.). The Law of the Single European Market. Oxford: Hart Publishing, 2002, p. 226 (passive mutual recognition); MICHAELS, S. Anerkennungspflichten im Wirtschaftsverwaltungsrecht der Europäischen Gemeinschaft und der Bundesrepublik Deutschland. Berlin: Duncker \& Humblot, 2004, p. 75 (abstrakt-antizipierte Anerkennung); KEESSEN, A. European Administrative Decisions. Groningen: Europa Law Publishing, 2009, p. 28 (single licence recognition); The German scholarship has frequently used the term transnationaler Verwaltungsakt, see e.g. NEßLER, V. Der transnationale Verwaltungsakt: zur Dogmatik eines neuen Rechtsinstituts. Neue Zeitschrift für Verwaltungsrecht, 1995, Vol. 32, no. 6, pp. 863-873 and RUFFERT, M. Der transnationale Verwaltungsakt. Die Verwaltung, 2001, Vol. 34, no. 3, pp. 453-470; The German terminology has influenced also scholarship in other jurisdictions, see e.g. BOCANEGRA SIERRA, R. and J. GARCIA LUENGO. Los actos administrativos transnacionales. Revista de administración pública, 2008, no. 177, pp. 9-29 and HANDRLICA, J. International administrative law and Administrative Acts. Czech Yearbook of Public \& Private International Law, 2016, Vol. 7, pp. 105-121.

23 See e.g. Act No. 361/2000 Coll., on road traffic, \ 104 (2), Act No. 21/1992 Coll., on banks, \5h (1), Act No. 256/2004 Coll., on capital market, \ 24 (1), Act No. 240/2013 Coll., on investment companies and investment funds, $\int 338$ (2).

24 Also here, the terminology varies in existing legal scholarship, see NGUYEN, M. Droit administratif international. Zeitschrift für schweizerisches Recht, 2007, Vol. 125, no. 3, p. 122 (décision de reconnaissance);MICHAELS, S. Anerkennungspflichten im Wirtschaftsverwaltungsrecht der Europäischen Gemeinschaft und der Bundesrepublik. Deutschland. Berlin: Duncker \& Humblot, 2004, p. 75 (konkret-aktuelle Anerkennung); KEESSEN, A. European Administrative Decisions. Groningen: Europa Law Publishing, 2009, p. 28 (mutual recognition decision).

25 See e.g. Act No. 561/2004 Coll., on schools, \ 106 (here, a recognition of foreign school-leaving certificates is labelled as a "nostrification").

26 WENANDER, H. Recognition of Foreign Administrative Decisions. Balancing International Co-operation, National Self-Determination, and Individual Rights. Zeitschrift für ausländisches öffentliches Recht und Völkerrecht, 2011, Vol. 71, pp. 780. 


\section{Review of literature}

When facing the qualification problem, the domestic administrative authority cannot apply any explicit general provision of municipal law addressing the issue. ${ }^{27}$ From a comparative perspective, this occurs quite frequently in European jurisdictions. The national reports, presented at the XIX ${ }^{\text {th }}$ Congress of the International Academy of Comparative Law, analysed the issue of recognition of foreign administrative decisions in 14 various jurisdictions. ${ }^{28}$ Among those, only the applicable law in Hungary provides for explicit provisions on validity and enforcement of foreign administrative decisions. ${ }^{29}$ However, this regulation represents a very rare exemption from a comparative perspective. By the absence of any explicit general provisions, the practice must turn to the legal scholarship to find solutions. Therefore, this section will be devoted to a brief overview of the existing literature addressing the subject of this article.

In the past, the qualification problem attracted the academic attention of those scholars dealing with a special field of law called international administrative law. In the Italian ${ }^{30}$ and German ${ }^{31}$ scholarship, this field of law emerged as a kind of a parallel to international private law. ${ }^{32,33}$ While international private law represents a special area of private law and governs relations of private law with certain foreign elements, international

27 Act No. 500/2004 Coll., on Administrative Proceedings deals merely with the situations, a foreign official document should be used as a proof in administrative proceeding in its $\int 53$ (4).

28 Australia, Brazil, Estonia, France, Germany, Greece, Hungary, Poland, Portugal, Spain, Sweden, Switzerland, Turkey and the United States. Further, the book also addresses recognition regimes established under the European Union and under the Andean Community.

29 See BALÁZS, I., M. NAGY a K. ROZSNYAI. La reconnaissance des actes administratifs étrangers en Hongrie. In: RODRIGUÉZ ARANA MUÑOZ, J. (ed.). Recognition of Foreign Administrative Acts. New York: Springer, 2016, pp. 193-194.

30 See FEDOZZI, P. Il diritto amministrativo internazionale (nozioni sistematiche). Perugia: Unione tipografica cooperativa, 1901, pp. 12-13; BISCOT'TINI, G. Diritto amministrativo internazionale. La rilevanza degli atti amministrativi stranieri. Padova: CEDAM, 1964; and BISCOTTINI, G. Diritto amministrativo internazionale. La circolazione degli nomini e delle cose. Padova: CEDAM, 1966.

31 See NEUMEYER, K. Vom Recht der Auswärtigen Verwaltung und verwandten Rechtsbegriffen. Archiv des öffentlichen Rechts, 1913, Vol. 31, pp. 129-135; STIER-SOMLO, F. Grundprobleme des internationalen Verwaltungsrechts. Internationale Zeitschrift für Theorie des Rechts, 1930/1931, Vol. 5, pp. 222-223; NEUMEYER, K. Internationales Verwaltungsrecht, Allgemeiner Teil. Zürich: Verlag J. Schweitzer (A. Sellier), 1936, pp. 19-20; STEINDORFF, E. Internationales Verwaltungsrecht. In: STRUPP, K. and H. SCHLOCHAUER (eds.). Wörterbuch des Völkerrechts. Berlin, 1962, pp. 581-582; BISCOTTINI, G. Diritto amministrativo internazionale. La rilevanza degli atti amministrativi stranieri. Padova: CEDAM, 1964, pp. 20-22; HOFFMANN, G. Internationales Verwaltungsrecht. In: MÜNCH, I. (ed.). Besonderes Verwaltungsrecht. Berlin, 1985, pp. 851-853 etc.

32 In our legal scholarship, the issue was addressed in the past by POTOČNÝ, M. Výklad českého mezinárodního práva správního [Interpretation of the Czech international administrative law]. In: Veřejná správa a právo: Pocta Dušanu Hendrychovi k 70. narozeninám [Public administration and the law: Homage to Professor Dušan Hendrych to his 70 ${ }^{\text {th }}$ birhday]. Praha: C. H. Beck, 1997, pp. 213-219.

33 See also HANDRLICA, J. A treatise for international administrative law. Lawyer Quarterly, 2020, Vol. 10, no. 4, pp. 283-296. 
administrative law has been understood as an integral part of administrative law, dealing with administrative relations where certain foreign elements ${ }^{34}$ appear. Thus, in both international private law and international administrative law, the term "international" refers merely to the foreign element involved and not to the area of international public law that exclusively governs relations between the States.

It was Karl Neumeyer, who argued that international administrative law (internationales Verwaltungsrecht) represents a special (sub)discipline of administrative law, governing administrative relations with foreign elements. ${ }^{35}$ Neumeyer claimed that while under international private law, the legal frameworks governing relations of private law in various States are understood as being normatively equal, under administrative law, such equality is not permissible.

Thus, administrative law, as a matter of principle, exclusively recognises its own rules as applicable in administrative relations and these rules are to be decided by the competent administrative authorities of the concerned State. Therefore, in contrast to the conflict-of-law norms of international private law, the rules of the international administrative law are not decisive in answering the question of applicable law (either domestic or foreign). They merely limit the application of municipal administrative law in those cases where a foreign element is involved and allow for validity of foreign measures. The norms, governing administrative relations with foreign elements were labelled as "delimiting norms" (Grenznormen) by Neumeyer. ${ }^{36}$ The doctrine, as developed by Neumeyer, tacitly implies that only lex for - i.e. applicable law of the competent administrative authority - can represent a solution of the qualification problem. ${ }^{37}$

The doctrinal approach of Neumeyer was further elaborated by Käte Weiß ${ }^{38}$ and Hannah Schwarz. ${ }^{39}$ They argued for a distinction between the recognition ex actu and the recognition ex lege. In the latter case, the effects of a foreign administrative decision arise directly from a delimiting norm, provided by the applicable law. Such norms can reflect certain obligations to recognise foreign administrative decisions, as provided by international agreements. The qualification problem may - in principle - arise with respect to both recognition ex actu and recognition ex lege. ${ }^{40}$ However, in the case of recognition ex actu, the qualification problem is limited to the case of ad hoc recognition of the respective foreign decision by the domestic administrative authority. Here, the effects for the domestic

\footnotetext{
34 E.g. foreign driving licence, foreign university diploma, foreign pilot licence or licence of a ship captain etc.

35 NEUMEYER, K. Internationales Verwaltungsrecht, Allgemeiner Teil. Zürich: Verlag J. Schweitzer (A. Sellier), 1936 , p. III.

36 Ibid, p. 225-226.

37 Ibid, p. 295.

38 WEIß, K. Die Anerkennung ausländischer Verwaltungsakte. Flenje: Verlag Seesen, 1932.

39 SCHWARZ, H. Die Annerkennung ausländischer Staatsakte. Berlin: Verlag Grünewald, 1935.

40 WEIß, K. Die Anerkennung ausländischer Verwaltungsakte. Flenje: Verlag Seesen, 1932. p. 21; SCHWARZ, H. Die Annerkennung ausländischer Staatsakte. Berlin: Verlag Grünewald, 1935, p. 30.
} 
legal framework subsequently arise from an act of recognition, i.e. from an act, issued by a domestic administrative authority. On the contrary, in the case of recognition ex lege, the qualification problem arises in those cases where statutory laws provide for any competence to address these foreign decisions (e.g. annul them, review them, restrict them etc.). The qualification problem was also addressed by Klaus König in his outstanding monograph, dealing with recognition of foreign administrative decisions. ${ }^{41}$ Here, König elaborated three varied approaches to the qualification of foreign administrative decisions. ${ }^{42}$ Firstly, application of lex causae would reflect the fact that a foreign administrative decision was issued in line with the applicable law of the State of origin. Consequently, lex causae would be a rational choice. However, such an approach would require that the competent administrative authority apply foreign law. Secondly, reflecting this obstacle, König argued for application of lex fori. In this context, König also argued ${ }^{43}$ for a third approach - autonomous qualification. However, such an approach would presume the existence of certain legal features that are independent from the forms of measures existing in the applicable legislation. The approach on qualification problem, as presented by König, has in the following decades been widely reflected in legal scholarship. ${ }^{44}$ Consequently, this article also considers the approach of König as a basic reference.

Lastly, Klaus Vogel's habilitation thesis on territorial application of administrative law ${ }^{45}$ deserves to be mentioned. Here, Vogel argued that, as a domestic administrative authority must always apply lex fori, no qualification problem can arise in administrative law. ${ }^{46}$ Under this understanding, the exclusive application of lex fori excludes any possibility to qualify a foreign administrative decision by using different criteria than those arising from municipal administrative law.

\section{The qualification problem}

Before addressing the qualification problem in detail, certain general remarks are appropriate in order to delimit this procedural issue:

- Firstly, the general framework, provided by the Act No. 500/2004 Coll., on Administrative Proceedings, does not address the issue of annulment, restriction,

41 KÖNIG, K. Die Anerkennung der ausländischen Verwaltungsakten. Köln: Verlag C. Heymann, 1965, pp. 32-35.

42 Ibid, pp. 34-35.

43 Ibid.

44 See PAPIER, H. and B. OLSCHEWSKI. Vollziehung ausländischer Verwaltungsakte. Deutsches Verwaltungsblatt, 1976, Vol. 103, p. 475; GLASER, M. Internazionale Verwaltungsbeqiebungen. Tübingen: Mohr Siebeck, 2005, p. 39; STELKENS, U. and M. MIRSCHBERGER. The Recognition of Foreign Administrative Acts: A German perspective. In: RODRIGUÉZ ARANA MUÑOZ, J. (ed.). Recognition of Foreign Administrative Acts, New York: Springer Verlag, 2016, p. 137.

45 VOGEL, K. Der räumliche Anwendungsbereich der Verwaltungsnorm. Frankfurt am Main: Alfred Metzner Verlag, 1965.

46 Ibid, p. 311. 
or review of any foreign administrative decisions. When addressing the decisions ${ }^{47}$, this statutory law refers exclusively to those decisions, issued by domestic administrative authorities. Consequently, any annulment, restriction or review vis-á-vis foreign administrative decisions would be - in principle - contradictory to this statutory law. At the same time, such measures will also be in conflict with the principles of international public law, which considers these acts as acta iure imperii and therefore, ban their annulment by other States. ${ }^{48}$

Thus, a domestic administrative authority possesses the competence to use any measures vis-á-vis a foreign administrative decision only in case a provision of the municipal law explicitly so provides. The qualification problem, as it's understood by this article, arises only in these cases. Otherwise, the domestic administrative authority is not entitled to execute any administrative measures towards foreign administrative decisions and consequently, a qualification problem cannot arise. The qualification problem is not necessarily linked to the feature of recognition. It appears merely as a product of a recognition, if municipal law provides for certain procedural measures, which are to be executed towards foreign administrative decisions.

- Secondly, the qualification problem represents an issue of procedural law. The domestic administrative authority is required to qualify the nature of a foreign administrative decision in order to proceed as required by the statutory law. By qualification, either the procedural law of the State of origin (lex causae), or the domestic procedural law (lex fori) may be considered. Consequently, the qualification problem, as understood by this article, does not address the issue of application of foreign, or domestic substantive law. Also, the qualification problem solely addresses the nature of the foreign administrative decision itself. Consequently, the solution of the qualification problem, as understood by this article, is not decisive for subsequent procedural measures, which always must be conducted pursuant to municipal law.

Taking these introductory remarks into consideration, the three various approaches to the qualification problem will be analysed from the viewpoint of municipal law.

\subsection{Lex causae}

Although gaining validity under our municipal law, a foreign administrative decision remains, to represent a measure issued pursuant to the applicable law of the State of origin. This concerns all three examples, given in the introduction to this article. The fact, that a foreign administrative decision is being recognised via a provision (delimiting norm) of the municipal law does not and cannot imply that such act becomes automatically a measure of our public administration. The legality of such foreign administrative

47 See Act No. 500/2004 Coll., on Administrative Proceedings, e.g. \ 70 (correction of formal defects), \ 77 (declaration of nullity), $\$ 97$ (annulment in a review proceeding) etc.

48 WENANDER, H. Recognition of Foreign Administrative Decisions. Balancing International Co-operation, National Self-Determination, and Individual Rights. Zeitschrift für ausländisches öffentliches Recbt und Völkerrecht, 2011, Vol. 71, pp. 762-770. 
decisions can be, in principle, assessed only pursuant to the applicable law of the State of origin. ${ }^{49}$

Having said this, one may argue for the use of lex causae in all cases, outlined in the introductory section. Using of lex causae in these cases would have two obvious advantages: Firstly, it will reflect the fact that a foreign universal visa, driving license, or license of an investment company remains to represent an administrative decision of the State of origin. Secondly, this approach would be capable to address potential gaps between legal features existing in the State of origin and in inland. ${ }^{50}$

However, the following considerations must be mentioned in regard to the potential use of lex causae in cases outlined in the introductory section of this article, as follows:

- Firstly, using lex causae for qualification of a foreign administrative decision contradicts the explicit provision of the Act No. 500/2004 Coll., on Administrative Proceedings $\mathrm{s}^{51}$, which requires that the domestic administrative authority applies exclusively statutory laws and international conventions that constitute a part of our legal order. Thus, the general regulation of administrative proceedings allows no application of foreign law. ${ }^{52}$ From a comparative perspective, one may argue that this feature, also labelled as the unity of the forum and the law ${ }^{53}$, represents an integral part of administrative law in various European jurisdictions. The reasons for exclusive application of municipal law by the competent authorities are twofold.

From a perspective of the State, allowing the application of foreign law vis-a-vis relations of public law, would interfere with the notion of sovereignty of the State. Here, a sovereign State is exclusively competent to govern its territory by his own municipal law. ${ }^{54}$ Allowing foreign law to govern relations of public law in our territory would contradict this concept.

From a perspective of a citizen, application of foreign law will be contradictory to the principle of legality of public administration. From a citizens' viewpoint, the public administration must be executed only "in cases and within the bounds provided for by law and only in the manner prescribed by law." 55 With regard to public administration, the Charter of Fundamental Rights and Freedoms explosively refers here to municipal law, which was duly approved and published. Consequently, application

49 KÖNIG, K. Die Anerkennung der ausländischen Verwaltungsakten. Köln: Verlag C. Heymann, 1965, p. 85.

50 See KEGEL, G. and K. SCHURIG. Internationales Privatrecht. 9. ed. München: C. H. Beck, 2004, p. 341.

51 Act No. 500/2004 Coll., on Administrative Proceedings, \ 2 (1).

52 See HANDRLICA, J. Foreign Law as Applied by Administrative Authorities. Zbornik Pravnog Fakulteta u Zagrebu, 2018, Vol. 68, no. 2, pp. 193-215.

53 See GROF, A. Zum “internationalen Verwaltungsrecht”. Juristische Blätter, 1986, Vol. 108, no. 2, p. 213.

54 HEMLER, A. Die Methodik der "Eingriffsnorm" im modernen Kollisionsrecht. Tübingen: Mohr Siebeck, 2019, pp. 62.

55 Constitutional Act No. 2/1993 Coll., Charter of Fundamental Rights and Freedoms, Art. 2 (2). 
of lex causae in a qualification problem will be - in principle - in strict contradiction with the requirements, as provided by both the Charter of Fundamental Rights and Freedoms and by the Act No. 500/2004 Coll., on Administrative Proceedings.

- Secondly, the scholarship of international administrative law argued ${ }^{56}$ that application of foreign law vis-á-vis matters of public law would be theoretically possible in case of a reference, provided by municipal law. However, such reference should be explicit enough to establish clarity concerning the fact that foreign law is to be applied and should also ensure accessible publication of such foreign law. If analysing the wording of the statutory laws, applicable in the three cases outlined in the introduction, we may argue that any reference is missing.

- Thirdly, use of lex causae would consequently imply that legality of qualification pursuant to this foreign law will be subject of judicial review by our domestic administrative courts. Consequently, the competent administrative courts will also be required to gain expertise in foreign law and apply it.

Despite certain arguments, which were expressed in favour of using lex causae, we can argue that the lex causae cannot represent a solution of the qualification problem under municipal law. The above-mentioned considerations are persuasive enough to reject this option.

\subsection{Lex fori}

Reflecting the requirement for the application of municipal law, as provided by the Act No. 500/2004 Coll., on Administrative Proceedings, one may argue that only lex for represents a solution of the qualification problem. If applying this approach in those cases outlined in the introductory section, the competent domestic administrative authority will be obliged to qualify the visa issued abroad, the foreign driving licence and also the foreign licence, enabling providing of investment services pursuant to those types of administrative measures, which are provided by the Act No. 500/2004 Coll., on Administrative Proceedings. A correct qualification is necessary for further application of procedural rules, governing prospective annulment ${ }^{57}$, or restriction ${ }^{58}$ of the foreign administrative decision.

While this approach has been traditionally favoured by the legal scholarship, here certain considerations must also be mentioned:

- Firstly, when applying lex fori for qualification of a foreign administrative decision, the domestic administrative authority will be required to find ${ }^{59}$ a corresponding form

56 VOGEL, K. Der räumliche Anwendungsbereich der Verwaltungsnorm. Frankfurt am Main: Alfred Metzner Verlag, 1965, p. 311; and OEHLER, C. Die Kollisionsordnung des Allgemeinen Verwaltungsrechts. Tübingen: Mohr Siebeck, 2005, pp. 314-315.

57 Regulation (EC) No 810/2009, Art. 34.1.

58 Act No. 240/2013 Coll., on investment companies and investment funds, $\int 539 \mathrm{~h}$.

59 See KMENT, M. Grenzüberschreitendes Verwaltungshandeln: Transnationale Elemente deutschen Verwaltungsrechts. Tübingen: Mohr Siebeck, 2010, pp. 259-260. 
of administrative measures among those provided by the Act No. 500/2004 Coll., on Administrative Proceedings. This approach has been labelled as Wirkungsangleichung (or Wirkungsgleichstellung) in German scholarship. ${ }^{60}$ Thus, the domestic administrative authority has to find the parallel of foreign administrative decisions and thus qualify it as a decision ${ }^{61}$, a certificate ${ }^{62}$, a public contract ${ }^{63}$ or as a measure of general nature. ${ }^{64}$ Here, the correct identification of the corresponding form constitutes a basic requirement for further procedural proceedings. However, due to absence of any harmonisation of the forms of administrative measures, the use of lex fori can lead to precarious situations, when an act will be qualified differently in the State of origin and in municipal law. Such situations will represent an inevitable result of the Wirkungsangleichung, as for the domestic administrative authority it will be not always possible to find a fully corresponding administrative measure as provided by the lex causae. In this regard, it was argued ${ }^{65}$ that a hypothetical situation may arise when the legal framework of the State of recognition will be unable to qualify the nature of the foreign administrative act, due to the absence of a corresponding measure.

- Secondly, the use of Wirkungsangleichung will imply that the qualification will be, to a certain extent, dependent on lex causae. ${ }^{66}$ Thus, in case of a foreign licence to provide investment services pursuant to Act No. 240/2013 Coll., the result of a qualification will depend on the measure issued by the competent authority of the State of origin. Consequently, such licence could be qualified as a decision pursuant to the second section of the Act No. 500/2004 Coll., on Administrative Proceedings. Depending upon the nature of the foreign licence, a qualification as a certificate under the fourth section of the referred statutory law would also be theoretically possible.

Subsequently, an inevitable link to the lex causae may cause differences in the legal position of the addresses of foreign administrative decisions. Thus, one can imagine a situation where a licence from State " $\mathrm{A}$ " will be subject to review proceedings towards a decision ${ }^{67}$, while - in parallel - a licence from a State "B" will be subject to review proceedings pursuant to the fourth section ${ }^{68}$ of the Act No. 500/2004 Coll., on Administrative Proceedings.

\footnotetext{
60 See BURBAUM, S. Rechtsschutz gegen transnationales Verwaltungshandeln. Baden: Nomos Verlag, 2003 , p. 31.

61 See Act No. 500/2004 Coll., on Administrative Proceedings, \68-70.

62 Ibid, $\int 154$.

63 Ibid, \159(1).

64 Ibid, $₫ 171$.

65 REINACHER, K. Die Vergemeinschaftung von Verwaltungsverfahren am Beispiel der Freisetzungsrichtlinie. Berlin: Tenea Verlag, 2005, pp. 65-66.

66 KMENT, M. Grenzüberschreitendes Verwaltungshandeln: Transnationale Elemente deutschen Verwaltungsrechts. Tübingen: Mohr Siebeck, 2010, p. 260.

67 Act No. 500/2004 Coll., on Administrative Proceedings, J 94-99.

$68 \mathrm{Ibid}, \int 156(2)$.
} 
- Thirdly, the use of Wirkungsangleichung may imply that the use of competence to annul or restrict a foreign administrative decision by a domestic administrative authority will have no appropriate funding in provisions of procedural law. The following example may enlighten this consideration: If a foreign licence pursuant to the Act No. 240/2013 Coll. is qualified as a public contract, the domestic authority will be required to apply the fifth section of the of the Act No. 500/2004 Coll., on Administrative Proceedings on the subsequent proceeding. However, while the provision of the Act No. 240/2013 Coll. calls ${ }^{69}$ for a restriction of foreign licence, the procedural provisions applicable do not provide for any restriction to be made ex offo. ${ }^{70}$

- Lastly, using lex fori in qualification problems may lead to a situation where the nature of a foreign administrative decision will be qualified and consequently, certain defects of such a decision will be identified. ${ }^{71}$ Here, a potential nullity of the respective decision represents a most problematic issue, as the reasons implying nullity under various jurisdictions vary considerably. ${ }^{72}$ In fact, the application of lex for may lead to a conclusion where a foreign administrative decision will be considered null. ${ }^{73}$ A problem arises, when the lex causae does not lead to the same conclusion, i.e. foreign administrative decision will be considered as valid in the State of origin. Here, the question arises if the domestic administrative authority would possess any competence to declare the nullity of such a foreign administrative decision.

The answer is rather negative: On one hand, the foreign administrative decision will be covered by the feature of acta iure imperii and thus a declaration of nullity would be contradictory to international public law. On the other, the application of municipal law ${ }^{74}$ in such a case will face severe difficulties, as identification of the administrative authority competent to declare such nullity will largely seem impossible. Further, when applying lex fori, an opposite constellation can also arise - i.e. qualifying a foreign administrative act, being null under the law of the State of origin, as valid in inland.

Consequently, application of lex forimay - theoretically - lead to a paradox in which a null decision will be "resurrected" in inland. However, doubts can be expressed towards the practical appearance and quantity of these cases.

\footnotetext{
$69 \int 539 \mathrm{~h}$.

70 Act No. 500/2004 Coll., on Administrative Proceedings, \94-99.

71 LUCIA, L. de. Administrative Pluralism, Horizontal Cooperation and Transnational Administrative Acts. Review of European Administrative Law, 2012, Vol. 5, no. 1, p. 34.

72 Ibid.

73 Act No. 500/2004 Coll., on Administrative Proceedings, \ 77.

74 Ibid.
} 
Here, one final remark must be made with regard to the application of lex fori towards foreign administrative decisions. Some authors ${ }^{75}$ have argued in the past that application of this approach vis-á-vis foreign administrative decisions would enable their review by the means of the administrative justice of the State of recognition. However, one must bear in mind, that such an approach goes far beyond the understanding of the qualification problem, as presented by this article. We understand that qualification problems only arise in those situations when a statutory law provides for an explicit competence of the domestic administrative authority to address a foreign administrative decision.

The above presented argumentation is not focused on qualification problems, as presented here. It rather aims to also enlarge the competence of administrative courts towards those foreign administrative decisions that are valid in the State of recognition. However, serious doubts can be expressed whether such approach will be in line with the principles of international public law, which in general prohibit any annulment or review of foreign acta iure imperii.

\subsection{Autonomous qualification}

In his monograph, dealing with the recognition of foreign administrative decisions, Klaus König elaborated one more proposal for solution of the qualification problem - an autonomous qualification. ${ }^{76}$ The concept of autonomous qualification presumes the existence of a legal form, provided by supra-national sources of law. Such legal forms must be independent enough in order to establish certain autonomous features. In other words, the autonomous qualification presumes an existence of an act sui generis. One may argue that the universal visa, as provided by the Regulation (EC) 810/2009, can serve as example of such a legal form. Based directly on the applicable Regulation, the visa issued by the competent consulate effects the entire EU, i.e. they are being recognised by the other Member States ex lege. At the same time, the Regulation provides ${ }^{77}$ for uniform material and formal content of the visa, thus enabling the argument for an autonomous feature. ${ }^{78}$

However, autonomous qualification of foreign administrative decisions would, in general, imply severe inconsistencies. Taking the Regulation (EC) 810/2009 as an example, we must bear in mind that a universal visa is to be issued in line with the applicable law of the competent consulate, in particular pursuant to the applicable procedural

75 See e.g. JARCK, C. Abänderung und Aufhebung ausländischer Staatshoheitsakte im internationalen Rechtsverkehr. Göttingen: Georg-August Universität, 1954, pp. 64-66; and more recently BASSI, N. Mutuo riconoscimento e tutela giurisdizionale. La circolazione degli effeti del provvedimento amministrativo straniero fra diritto europeo e protezione degli interessi del terzo. Milano: Ed. Guiffré, 2008, p. 76.

76 KÖNIG, K. Die Anerkennung der ausländischen Verwaltungsakten. Köln: Verlag C. Heymann, 1965, p. 20.

77 Regulation (EC) 810/2009, Annex VII.

78 HANDRLICA, J. Is there an EU international administrative law? A juristic delusion revisited. European Journal of Legal Studies, 2020, Vol. 12, no. 2, pp. 1-38. 
rules. The lack of procedural harmonisation implies that we can only barely opt for an autonomous qualification here. Analysing the two remaining examples, given in the introductory section to this article, will further support denial of autonomous qualification. While both the recognition of foreign driving licences and licences for providing investment services reflects obligations of the State arising from supra-national sources of law, both these decisions are to be issued in line with the applicable procedural law of the competent authority. Consequently, one can only barely argue for an autonomous character of these decisions.

Taking all mentioned considerations into account, this article argues that despite certain shortcomings, the only viable option to address the qualification problem in municipal law is represented by application of lex fori.

\section{Conclusions}

This article aimed to address the qualification problem in municipal law. It reflects both the rising number of cases when the EU law requires recognition of foreign administrative decisions and the ongoing academic discussion abroad. It understands the qualification problem as a procedural issue, which arises in those situations municipal law requires for annulment, review or restriction vis-á-vis a foreign administrative decision. It must be emphasised that such situations are rare and exceptional, as foreign administrative decisions, in principle, constitute "acta iure imperii" and as such, cannot be subject to any review by domestic administrative authorities.

When addressing a foreign administrative decision, the domestic administrative authority must identify adequate qualifications. This qualification is a procedural one. Thus, it does not concern substantive law. The correct qualification of the nature of the foreign administrative decision is necessary to support the legality of the subsequent administrative proceedings. Here, three various options may be considered:

Firstly, a qualification based on lex causae, which would be in line with the fact that the foreign administrative decision remains to represent a foreign decision even after being recognised. However, a number of severe conflicts may be identified in this concern. Secondly, a qualification based on lex fori comes into consideration, which has been traditionally supported in legal scholarship. Lastly, some scholars proposed an autonomous qualification as a solution of the problem.

This article argues that only lex for $i$ can represent a solution of the qualification problem under municipal law. Despite certain practical shortcomings, identified in the third section of this article, only the application of lex for represents an option that is in line with the requirements of the Charter of Fundamental Rights and Freedoms. 